\title{
Compliance-based estimation of seismic collapse risk of an existing reinforced concrete frame building
}

\author{
Anastasios Tsiavos $^{1}$ (D) Pascal Amrein ${ }^{1} \cdot$ Nathan Bender $^{1} \cdot$ Bozidar Stojadinovic $^{1}$
}

Received: 2 March 2021 / Accepted: 25 August 2021 / Published online: 3 September 2021

(c) The Author(s) 2021

\begin{abstract}
Seismic evaluation of existing structures is based on determining the damage likely to occur during the lifetime of these structures due to earthquake ground motion excitation. However, there is not a consensus about the acceptable level of seismic damage, the expected lifetime of these structures, and the seismic hazard level(s) to evaluate the structures at. This paper presents a methodology for a parametric calculation of the seismic collapse risk of an existing Reinforced Concrete (RC) frame building based on its seismic code compliance, quantified by a dimensionless metric. This metric, defined as compliance factor, compares the seismic capacity of an existing structure with the seismic demand for a new structure at a predetermined hazard level. The inelastic seismic behavior of four models of the RC frame building of varying compliance was analytically investigated in this study to demonstrate the novel methodology. The four models of the RC building were chosen to represent existing RC frame structures designed and constructed before the introduction of modern seismic code provisions. These four building models were excited by a group of earthquake ground motion excitations using Incremental Dynamic Analysis. The collapse probabilities of the four building models, representing varying values of seismic code compliance, were determined for two different locations corresponding to regions of moderate and high seismic hazard, thus laying the basis for the compliance-based estimation of the seismic collapse risk of existing structures.
\end{abstract}

Keywords Seismic evaluation of structures - Compliance factor · Probability of collapse · $\mathrm{RC}$ frame buildings

\section{Introduction}

A large percentage of the existing housing inventory worldwide consists of buildings designed before the adoption and enforcement of the modern seismic design codes. Therefore, most of these buildings do not comply with the current seismic code provisions and are exposed to a higher seismic damage risk compared to a new structure. The seismic evaluation and rehabilitation of these buildings is of utmost importance for the maintenance of

Anastasios Tsiavos

tsiavos@ibk.baug.ethz.ch

1 Department of Civil, Environmental and Geomatic Engineering, ETH Zurich, Zurich, Switzerland 
public safety as well as for the preservation of the cultural heritage of our communities. However, the seismic evaluation and the prioritization of the seismic retrofitting of a portfolio of existing buildings (Grant et al. 2007; Crowley et al. 2008) necessitate the determination of their seismic vulnerability and seismic risk.

The assessment of the seismic vulnerability, as an essential component of the determination of the seismic risk of existing buildings, can be performed using three different approaches: An approach based on seismic damage observed in past earthquake events (Anagnos et al. 1995), an approach based on analytical simulation of the inelastic seismic response of buildings (Silva et al. 2019) and a third approach, which is defined as hybrid vulnerability assessment and is based on an efficient combination of the advantages of the first two approaches (Kappos et al. 2006).

The lack of adequate seismic damage data from past earthquakes inhibits the sufficiency of the implementation of a pure empirical approach for the assessment of the seismic vulnerability of RC buildings. Hence, a wide range of analytical methodologies have been proposed during the last decades for the determination of fragility curves towards the assessment of the seismic vulnerability of existing RC buildings. Singhal and Kiremidjian (1996) performed nonlinear dynamic analyses of RC frame buildings subjected to artificial ground motion records to propose analytical fragility curves based on the Park-Ang global damage indices (1985). The application of a similar methodology was presented by Masi (2003) for the determination of fragility curves of post-1970 RC buildings designed only for vertical loads, including two additional RC building configurations: RC buildings with masonry infills and Pilotis frames. Zeris et al. $(2002,2006)$ highlighted the importance of conducting nonlinear dynamic analysis for an accurate estimation of the local inelastic deformation demand of RC frame buildings, designed before the adoption of the modern seismic code provisions. The use of a predetermined, finite number of natural or artificial ground motion records for the derivation of the aforementioned fragility curves leads to a discrete representation of the seismic vulnerability of RC buildings. Nevertheless, the increase of the accuracy of this representation necessitates the use of a large set of ground motion records for the conduction of nonlinear dynamic analysis, which can lead to high computational cost.

In light of the aforementioned limitations, the use of the Capacity Spectrum Method (Fajfar 1999) and the Static Pushover Analysis were proposed for a simplified and highly efficient estimation of the seismic vulnerability of RC buildings (FEMA HAZUS 2003; Borzi et al. 2008; Fardis et al. 2012; Milosevic et al. 2020). Pinho et al. (2006, 2013) presented a comprehensive analysis of the displacement dispersion obtained by five different nonlinear static procedures for the seismic assessment of existing frame buildings. These methodologies provide a continuous representation of the seismic vulnerability of existing buildings and can be easily applied by the civil engineering community due to their simplicity (D'Ayala et al. 2015; Beyer et al. 2015). However, these methods do not consider the dynamic effect of earthquake ground motion excitation on the inelastic response and seismic damage of existing buildings.

The use of Incremental Dynamic Analysis-IDA (Vamvatsikos and Cornell 2002) emerged from the necessity for a fine balance between the consideration of ground motion variability and the continuous representation of the seismic vulnerability of RC buildings. A software tool (SPO2IDA) was proposed by Vamvatsikos and Cornell (2006) to simplify the use of IDA and reduce its computational cost. Chaulagain et al. (2016) employed SPO2IDA for the assessment of the seismic vulnerability of RC frame buildings in Nepal. Dolšek $(2008,2010)$ developed a software tool based on Matlab (MathWorks 2007) and OpenSees (McKenna et al. 2000), which automates the application of IDA for the seismic 
performance assessment of RC frames. Zeris and Repapis (2018) and Carvalho et al. (2012) compared the use of Static Pushover Analysis and Dynamic Analysis for the assessment of the seismic performance of existing RC buildings.

A common theme across the aforementioned studies is the significant dependence of the fragility curves on the compliance of the RC structure to the seismic code provisions, which is usually defined on a qualitative basis. However, the use of a normalized metric for the quantification of the compliance of these buildings to seismic code provisions would shed more light in the correlation between the code compliance of these buildings and their seismic vulnerability. The quantification of this correlation would make these curves comparable with other fragility curves developed for similar building configurations subjected to the same seismic code provisions. Furthermore, the quantification of the code compliance of these buildings can lead to the determination of their seismic collapse risk (Elwood et al. 2012; Liel et al. 2017; Duvernay et al. 2018; Žižmond and Dolšek 2019, Shahnazaryan and O'Reilly 2021) and can justify the application of seismic retrofitting towards the mitigation of this risk (Galanis et al. 2018). However, the assessment of seismic code compliance of existing buildings on a qualitative basis inhibits the accurate estimation of the implications of their compliance on their seismic collapse risk.

In view of this challenge, the use of ratios that express the capacity of an existing structure over its seismic demand has been proposed by several researchers in the past to provide a quantitative probabilistic framework for the performance-based seismic evaluation of existing structures. Cornell et al. (2002) and Jalayer and Cornell (2002) suggested the use of the ratio of the factored demand over the factored capacity of an existing structure, considering aleatory and epistemic uncertainties. Jalayer et al. (2007) proposed the use of this ratio for the structural element that corresponds to the most critical failure mechanism for the system. A simplified form of this ratio that utilizes a seismic design spectrum for the determination of the seismic demand is defined in the Swiss Seismic Code Provisions (SIA 2017) to quantify the seismic code compliance of existing structures. This ratio $\alpha_{S}$ denotes the strength-based compliance factor of an existing structure, defined as (SIA 2017):

$$
a_{s}=\frac{C_{e}}{C_{c}}
$$

where $C_{e}$ represents the seismic strength capacity of an existing structure and $C_{c}$ denotes the seismic strength demand for a new, code-compliant structure designed at the same location. The corresponding displacement-based compliance factor of an existing structure is defined as (SIA 2017):

$$
a_{D}=\frac{D_{e}}{D_{c}}
$$

where $D_{e}$ represents the seismic displacement capacity of an existing structure and $D_{c}$ denotes the seismic displacement demand for a new, code-compliant structure designed at the same location. Within this frame, the determination of the strength- and displacementbased compliance of an existing structure can be demonstrated using a base shear coefficient $C_{b}$ vs. displacement $S_{d}$ spectrum in a format similar with the Capacity Spectrum method (Freeman et al. 1975; Freeman 1998) and the N2 method (Fajfar 1999): Figs. 1, 2 and 3 illustrate the determination of the compliance of three types of seismically deficient existing structures, assuming in the general case that the strength of the existing and the corresponding new, code-compliant structures (expressed in terms of base shear coefficient $\left.C_{b}=S_{\mathrm{a}} / \mathrm{g}\right)$ are lower than the strength demand given by an elastic design spectrum $C_{c, \text { elastic }}$. 


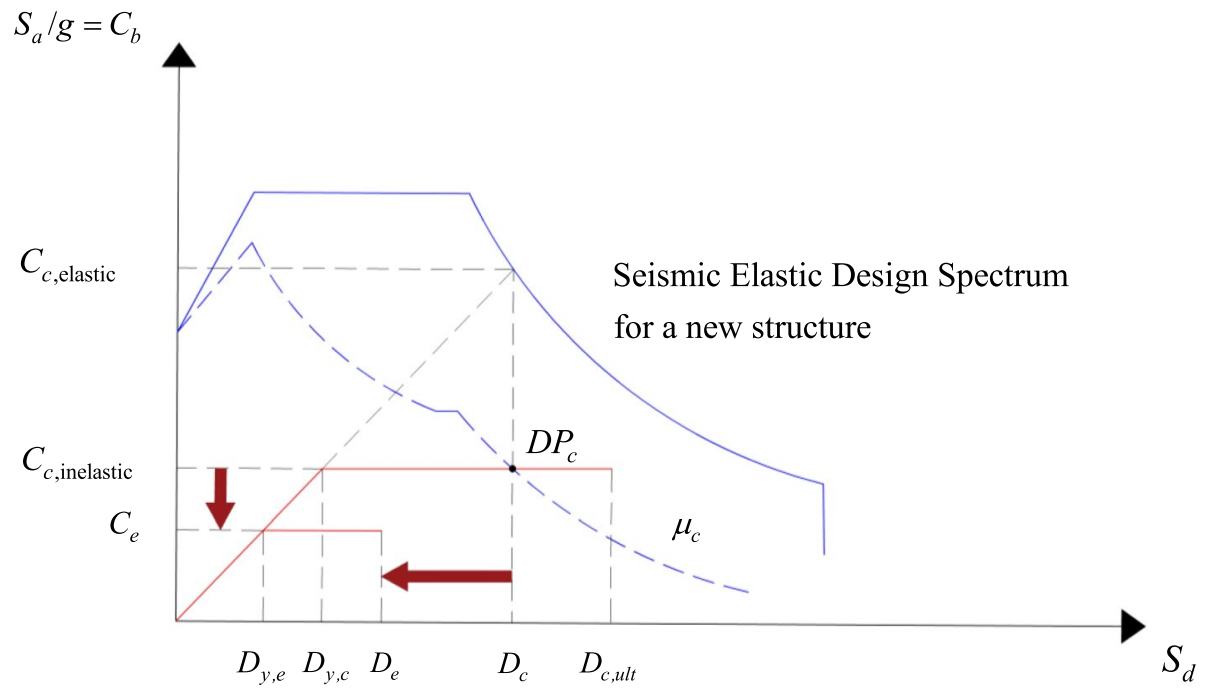

Fig. 1 Strength-based compliance factor $\alpha_{s}$ and displacement-based compliance factor $\alpha_{D}$ for a strengthand displacement-deficient existing structure $\left(\alpha_{s}<1, \alpha_{D}<1\right)$

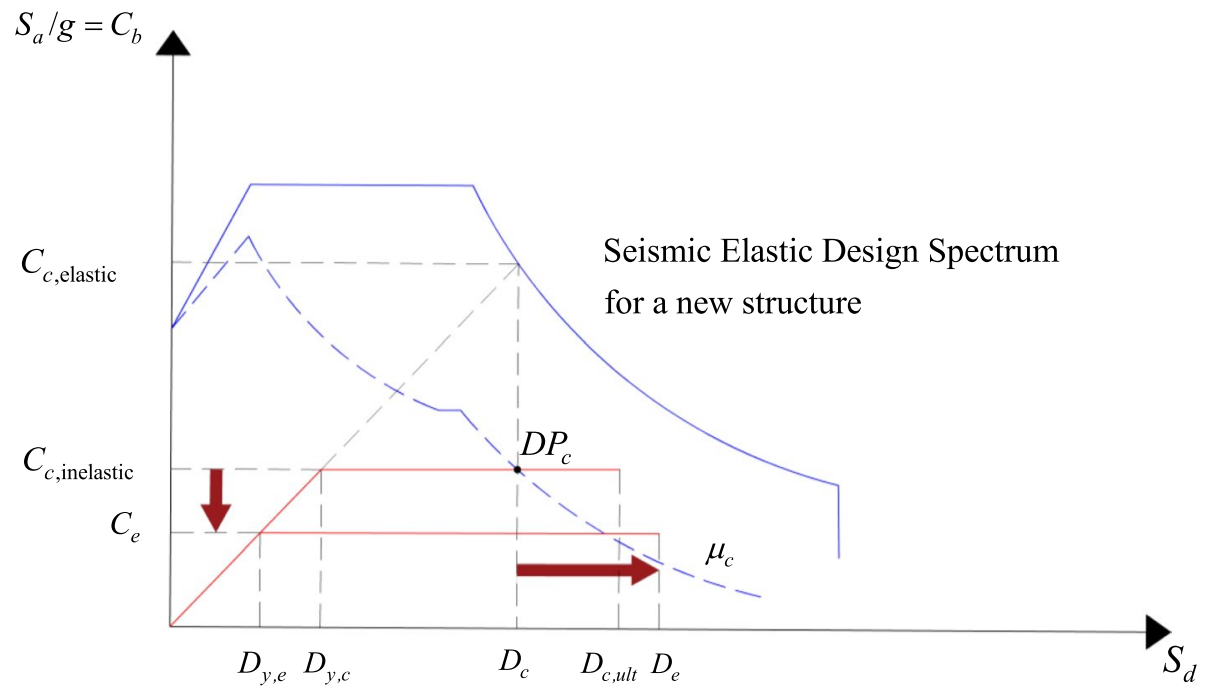

Fig. 2 Strength-based compliance factor $\alpha_{s}$ and displacement-based compliance factor $\alpha_{D}$ for a strengthdeficient existing structure $\left(\alpha_{s}<1, \alpha_{D}>1\right)$

Figure 1 shows this determination for a strength- and displacement-deficient existing structure, whose strength capacity $C_{e}$ and displacement capacity $D_{e}$ are both lower than the corresponding demand values $C_{c}$ and $D_{c}$ determined for a new structure at the same location, so that $\alpha_{s}<1$ and $\alpha_{D}<1$ [Eqs. (1), (2)]. The aforementioned capacity values $C_{e}$ and $D_{e}$ are obtained from the idealized pushover curve of the equivalent 


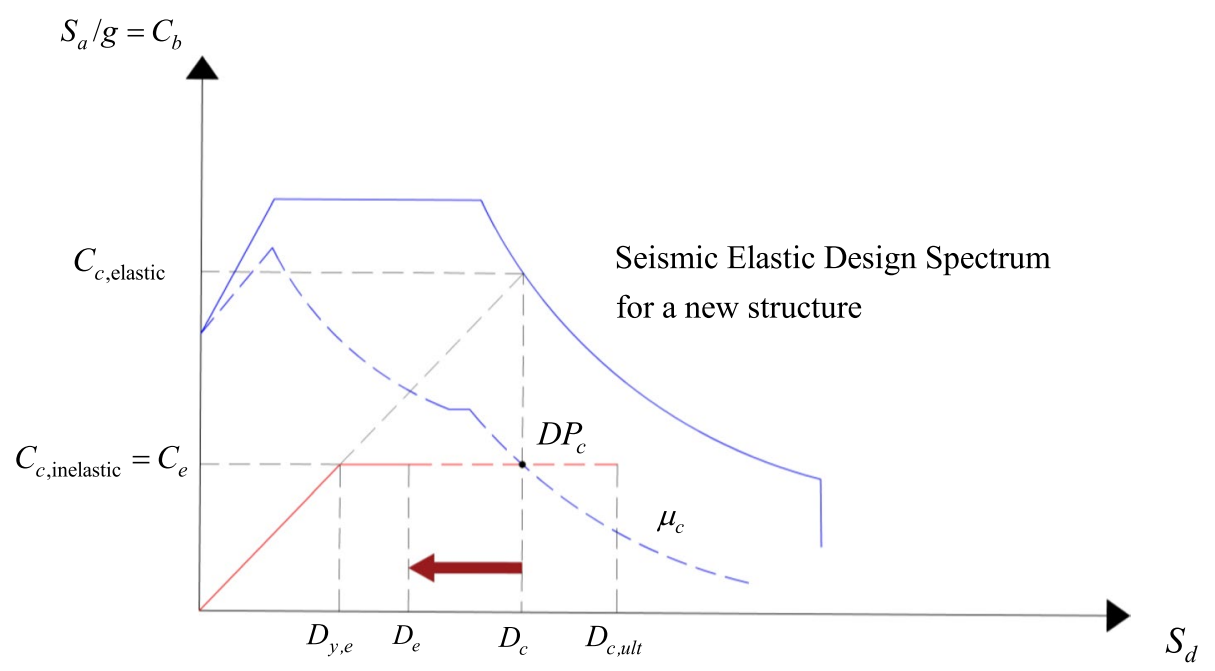

Fig. 3 Strength-based compliance factor $\alpha_{s}$ and displacement-based compliance factor $\alpha_{D}$ for a displacement-deficient existing structure $\left(\alpha_{s}=1, \alpha_{D}<1\right)$

SDOF system of the existing structure (EC8 2004; Fajfar 1999). The corresponding displacement demand $D_{c}$ is derived by the intersection (Demand Point $D P_{c}$ ) of the inelastic demand spectrum for the new, code-compliant structure with the idealized pushover curve of the new structure with strength $C_{c}$ and displacement capacity $D_{c, u l t}$. Figure 2 elucidates the determination of the compliance of a strength-deficient existing structure $\left(\alpha_{s}<1\right)$ whose displacement capacity is greater than the demand for a new structure $\left(\alpha_{D}>1\right)$. The compliance of a displacement-deficient existing structure $\left(\alpha_{D}<1\right)$ is shown in Fig. 3 for the case of $\alpha_{s}=1$, representing cases in which the existing structure has the same strength with the new structure, but lower displacement capacity.

Tsiavos et al. (2018) and Bender et al. (2017, 2019) proposed the use of compliance factors for the estimation of seismic risk of existing structures using constantperiod and constant-yield-displacement approaches (Tsiavos and Stojadinovic 2019). Nevertheless, the simplified fragility curves used in these studies limited their application spectrum to non-ductile RC buildings, such as the one investigated by Fardis and Negro (2005), Bento et al. (2010) and Belejo et al. (2017), which collapse immediately after the exceedance of a predetermined ground motion intensity measure. In an extension, this study aims to integrate the compliance factor-based metric in a comprehensive approach for the estimation of the seismic collapse risk of existing RC frame buildings.

Along these lines, the goal of this study is to parametrize the probability of collapse of existing buildings using strength-based compliance factors and to derive compliancebased fragility curves that represent the behavior of a typical example of RC frame buildings, constructed before the adoption of modern seismic code provisions. The illustration of this correlation between compliance and seismic risk will lay the basis for the risk-based seismic evaluation of existing structures and the decision making about the seismic retrofit of these structures, based on a targeted seismic risk level that is accepted by our communities. 


\section{Methodology}

The methodology proposed in this paper includes three steps:

1. Estimation of seismic hazard in the location of the RC building.

2. Determination of the compliance of the $\mathrm{RC}$ building to the existing seismic code provisions.

3. Quantification of the seismic risk of the RC building, expressed by its probability of collapse.

\subsection{Estimation of seismic hazard in the location of the RC building}

The first step of the proposed methodology comprises the estimation of the seismic hazard in the location of the building through the use of seismic hazard curves: These curves show the probability that an earthquake intensity level is exceeded during a predetermined time period. The Peak Ground Acceleration (PGA) was chosen as the earthquake intensity measure (IM) in this study to facilitate a comparison of the analytically derived results with data obtained from experimental campaigns conducted using the chosen $\mathrm{RC}$ frame building that are based on the excitation of the structure with different PGA levels (Fardis 1996; Dolšek 2008, 2010). Furthermore, the choice of PGA as an IM facilitates a comparison of this study with the analytically derived, PGA-based fragility curves developed for RC frame buildings of varying compliance to seismic code provisions, such as the ones determined by Kappos et al. (2006) and the PGA-based fragility curves considering ageing effects on RC frame buildings (Couto et al. 2020). Kostinakis et al. (2015), Cantagallo et al. (2012), Yakut and Yilmaz (2008) and Iervolino et al. (2018), among others, demonstrated the high correlation of the spectral acceleration at the fundamental period of the structure with the maximum and average interstorey drifts of $\mathrm{RC}$ buildings, indicating that such period-dependent intensity measure could be more appropriate. However, Cantagallo et al. (2012) suggest the use of the cracked (secant) period of the structure to select a spectral acceleration as an intensity measure: determining such a period for an existing building is not easy in practice, considering the variations from the as-designed state due to construction, use and ageing. Within this frame, the use of a vibration-period-independent IM in this study is a good compromise between simplicity, computational efficiency and accuracy.

Two different locations have been chosen to represent the effect of two different seismic hazard levels on the seismic risk of existing RC buildings: Sion, Switzerland and Athens, Greece. The seismic hazard curves for both regions are determined using the seismic hazard platform of the European Facilities for Earthquake Hazard and Risk (EFEHR 2017) and are shown in Fig. 4. 


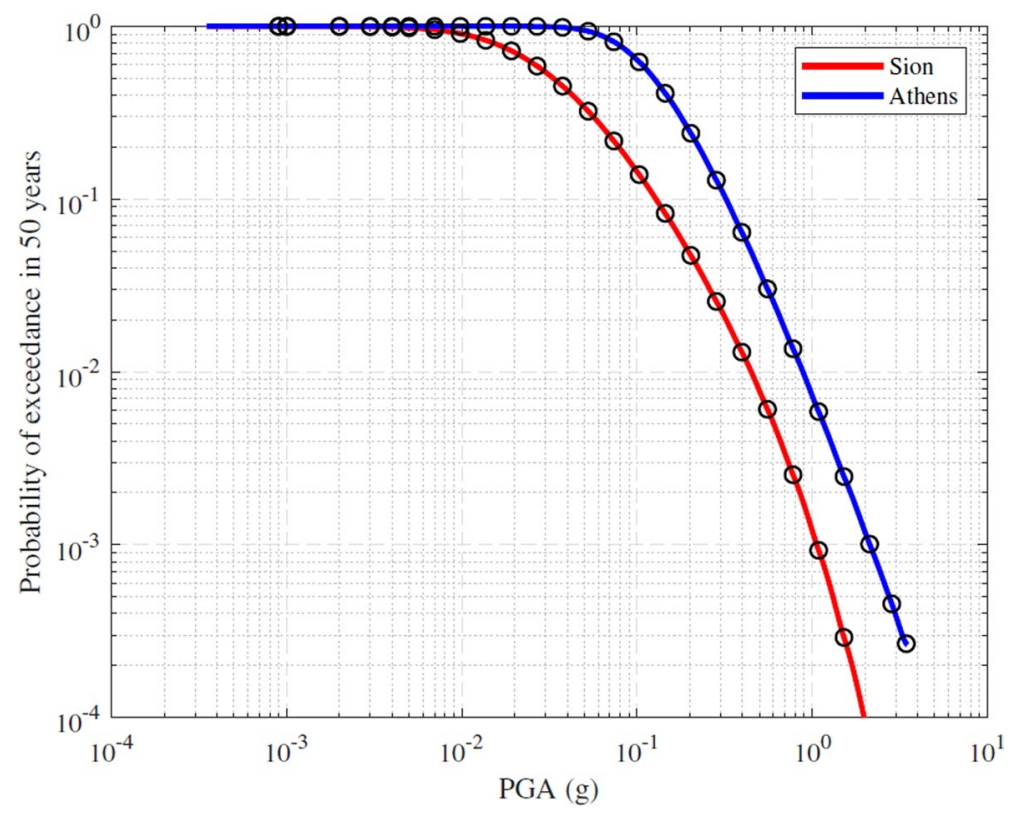

Fig. 4 Seismic hazard curves for Sion (Switzerland) and Athens (Greece)

\subsection{Determination of the compliance of the RC building to the existing seismic code provisions}

\subsubsection{Numerical simulation of the RC building}

The second step of the methodology proposed in this study consists of the determination of the strength-based compliance factor $\alpha_{s}$ of a RC building through the numerical simulation of the inelastic behavior of the building.

A four-storey RC frame building with masonry infills (Dolšek 2010) was chosen to simulate the design standards for RC frame buildings constructed between 1970 and 1980 , thus illustrating the methodology proposed in this study. The geometry and the reinforcement of the building, defined as Model A, are shown in Fig. 5. The slab thickness is $15 \mathrm{~cm}$. The concrete quality used for the construction of the building is C25/30, while the quality of the steel reinforcement is B500. The floor masses of the building are: $87 \mathrm{t}$ (first floor), $86 \mathrm{t}$ (second and third floor) and $83 \mathrm{t}$ (fourth floor). The design base shear of the building is $529 \mathrm{kN}$ (Fardis 1996). The transverse reinforcement of the beams and columns was capacity-designed to promote flexural plastic hinge formation. Stirrups $\varnothing 10 / 100$ are used in the critical regions of columns (Negro et al. 1994). The vibration periods of the first three vibration modes of the building and the corresponding mass participation ratios are shown in Table 1.

The numerical model of the building was generated using OpenSees (McKenna et al. 2000) and the PBEE toolbox (Dolšek 2010) and consists of beam and column elements. The floor slabs are assumed to be rigid in their plane. 


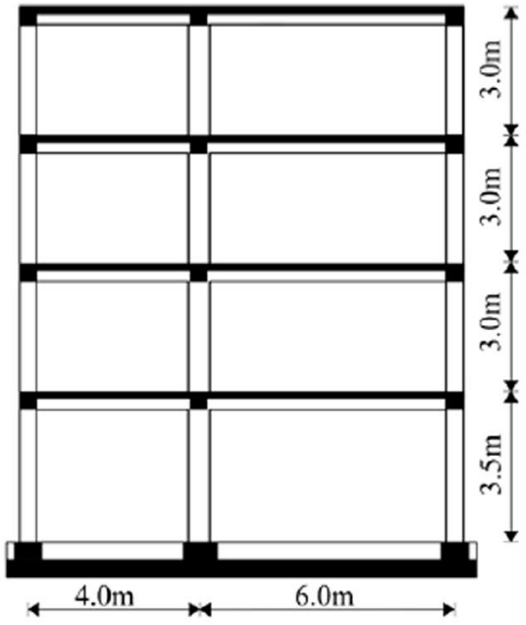

Reinforcement of columns at the base:

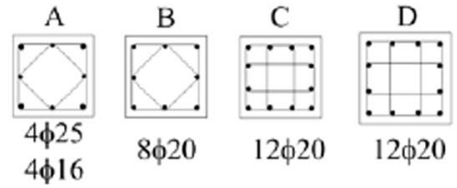

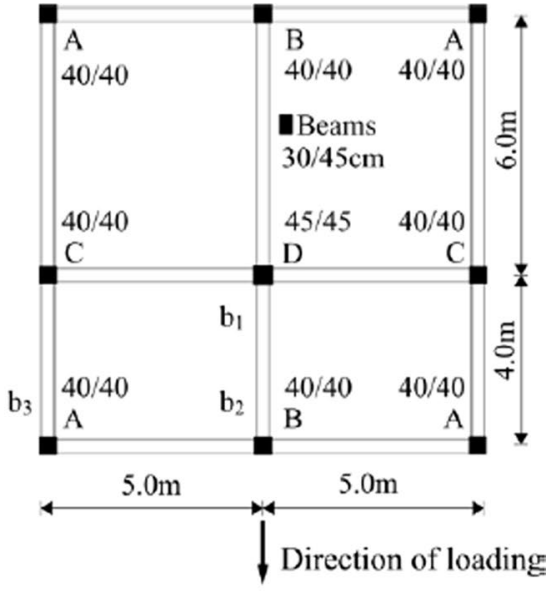

Typical reinforcement in beams in first storey: Location $b_{1}: \quad$ Location $b_{2}: \quad$ Location $b_{3}$ :

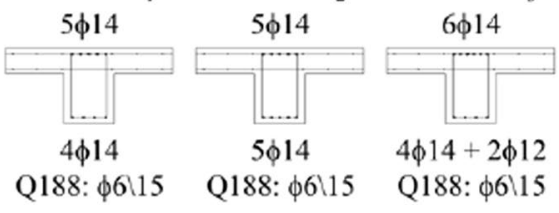

Fig. 5 Four-storey RC building designed by Fardis (1996) according to EC8 and investigated by Dolšek (2008, 2010)

Table 1 Periods and mass participation ratios of the first three vibration modes of the building

\begin{tabular}{llll}
\hline Vibration period & $\mathrm{T}_{1}(\mathrm{~s})$ & $\mathrm{T}_{2}(\mathrm{~s})$ & $\mathrm{T}_{3}(\mathrm{~s})$ \\
& 0.664 & 0.604 & 0.448 \\
Mass participation ratio & $\mathrm{M}_{1}$ & $\mathrm{M}_{2}$ & $\mathrm{M}_{3}$ \\
& $65 \%$ & $25 \%$ & $4 \%$ \\
\hline
\end{tabular}

\subsubsection{Moment-rotation relation}

The use of the PBEE toolbox (Dolšek 2010) enabled the simulation of the inelastic behavior of the columns and beams of the existing RC frame building using plastic hinges with a trilinear moment-rotation relation and material softening (Dolšek 2008). The plastic hinges, modelled as zero-length elements are introduced in the beginning and the end of each structural element of the model (Amrein 2020; Dolšek 2008), using a uniaxial hysteretic material model (Mazzoni et al. 2006). An elastoplastic strain-stress relationship is used for the steel bars, whereas in the case of the concrete the stress-strain relationship prescribed in EC 2 (2004) for non-linear analysis is assumed for calculation of the moment-curvature relationship. The moment-curvature analysis is performed up until the ultimate deformation of the concrete $\varepsilon_{c u}=-3.50 \%$ o or the ultimate deformation of the reinforcing steel $\varepsilon_{s u}=10 \%$. For the beams, the plastic 
hinge was used for major axis bending only. For the columns, two independent plastic hinges for bending about the two principal axes were used.

\subsubsection{Pushover curve}

The force distribution for the application of the horizontal, incrementally increasing static load to the RC frame building is determined by the multiplication of the fundamental mode shape with the floor masses. The nonlinear static analysis includes the P-Delta effects. The pushover curve for the building presented in Fig. 5 is shown in Fig. 6 and is similar to the one obtained by Dolšek (2008) for the same building. A bilinear approximation of the pushover curve is presented on the same Figure. This bilinear approximation is based on the principle of equal areas under the curves (Fajfar 1999), considered up to the point where the first significant drop in strength (usually about 20\%) occurs in the nonlinear, actual pushover curve, as proposed by Kappos et al. (2006) and Kappos and Panagopoulos (2010).

\subsubsection{Determination of the strength-based compliance of the RC building}

The strength-based compliance factor $\alpha_{s}$ of the RC building [Eq. (1)] was used to define and parametrize its seismic compliance. The elastic seismic design spectra for a new building located in Athens, Greece (Soil Class A, ZII, $\alpha_{g d}=0.24 \mathrm{~g}$ ) and a new building located in Sion, Switzerland (Soil Class B, Z3b, $\alpha_{g d}=0.16 \mathrm{~g}$ ) are used to define the base shear coefficient demand $C_{c}$ and are presented in Fig. 7, using the spectrum format presented in Fig. 1, 2 and 3. The EC8 (2004) elastic design spectrum for $\alpha_{g d}=0.24 \mathrm{~g}$ is presented in the same Figure. The use of elastic design spectra was chosen for the definition of the code-compliant new building as a special case of the inelastic design approach shown in Figs. 1, 2 and 3 to facilitate a consistent comparison between the seismic design spectra corresponding to Sion, Athens and EC8 (2004).

The base shear coefficient-displacement $\left(C_{b}-S_{\mathrm{d}}\right)$ capacity of the building is derived by the transformation of the MDOF system to a SDOF system, prescribed by EC8 (2004), using the values derived from the eigenvalue analysis for the numerically simulated

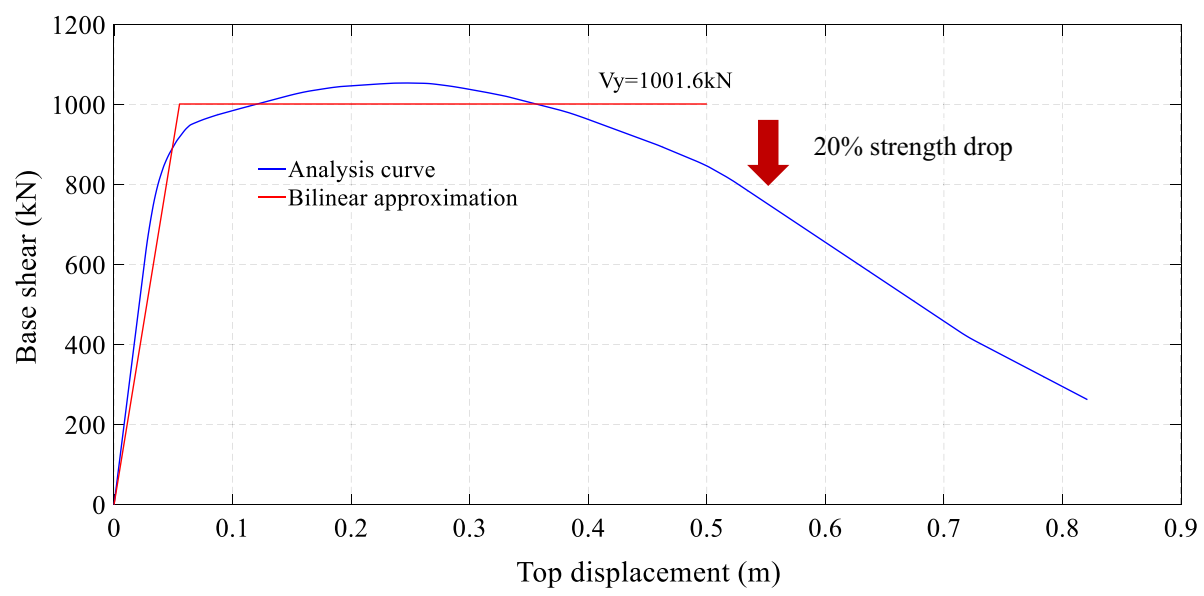

Fig. 6 Analytical and bilinearized pushover curve of the RC frame building 


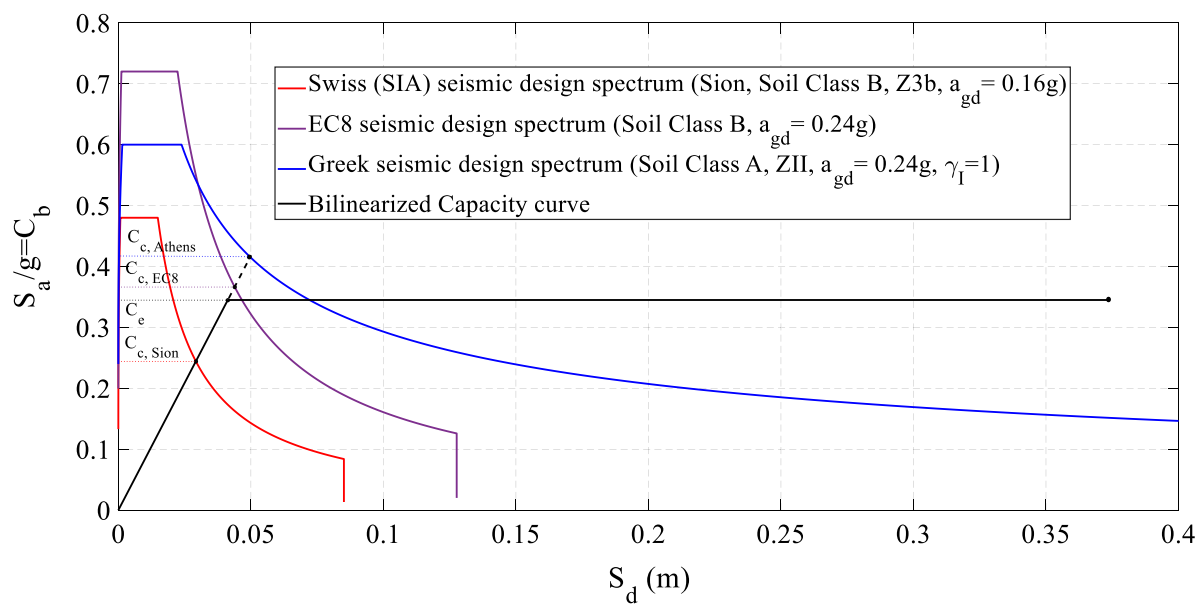

Fig. 7 Determination of the compliance of the RC frame building to seismic code provisions

building $\Gamma=1.34$ and $m^{*}=217.44$ t. However, a linear fundamental mode shape can be assumed in the general case to relate the interstorey drift, the maximum displacement and the displacement of the equivalent SDOF system of the building $S_{d}$, when a finite element model of the building is not available. As shown in Fig. 7, the strength capacity of the existing building is $C_{e}=0.35$, while the corresponding demand for a new building designed in Athens is $C_{c}=0.42$. Hence, the strength-based compliance factor of the building is $\alpha_{s}=0.35 / 0.42=0.84$ [Eq. (1)] for Athens, while the corresponding value for Sion is $\alpha_{s}=0.35 / 0.25=1.4$. The EC8-based compliance factor for $\alpha_{g d}=0.24 \mathrm{~g}$ is $\alpha_{s}=0.35 / 0.37=0.95$.

\subsection{Quantification of the seismic risk of the RC building}

The last step of the proposed methodology comprises the compliance-based determination of the seismic risk of the building, expressed by its probability of collapse.

\subsubsection{Incremental dynamic analysis}

Incremental Dynamic Analysis (Vamvatsikos and Cornell 2002) is used in this study to determine the maximum interstorey drift of the RC frame building presented in Fig. 5 for varying values of the chosen Intensity Measure (PGA). Each IDA curve is derived from the nonlinear dynamic analysis of the RC building subjected to an incrementally scaled ground motion record and comprises 20 points. These points correspond to 20 increments of the PGA of the scaled record, as performed by Tsiavos and Stojadinovic (2016). The scaling is automated by the PBEE toolbox using a hunt and fill algorithm developed by Vamvatsikos and Cornell (2004). The ground motion ensemble chosen for the conduction of the IDA comprises 12 ground motions, obtained from the PEER ground motion database (2018). The ground motion ensemble is shown in Table 2. The minimum and maximum scaling factors for the motions used in the IDA analysis are shown in the same Table. 
Table 2 List of recorded earthquake ground motions (PEER NGA Database 2018) used for the excitation of the RC frame building

\begin{tabular}{|c|c|c|c|c|c|c|c|}
\hline No. & Date & Earthquake & Station & $M_{w}$ & $R(\mathrm{~km})$ & Scale factor min & $\begin{array}{l}\text { Scale } \\
\text { factor } \\
\text { max }\end{array}$ \\
\hline 1 & 28/6/1966 & Parkfield & $\begin{array}{l}\text { Cholame-Shandon } \\
\text { Array } 12\end{array}$ & 6.19 & 17.64 & 0.35 & 3 \\
\hline 2 & $15 / 10 / 1979$ & San Fernando & Palmdale Fire Station & 6.61 & 24.16 & 0.22 & 2.4 \\
\hline 3 & 23/11/1980 & Irpinia & Auletta & 6.2 & 28.69 & 0.25 & 2.7 \\
\hline 4 & $23 / 11 / 1980$ & Irpinia & Rionero In Vulture & 6.2 & 22.68 & 0.21 & 2.4 \\
\hline 5 & 08/07/1986 & $\begin{array}{l}\text { N. Palm } \\
\text { Springs }\end{array}$ & Joshua Tree & 6.06 & 23.2 & 0.18 & 2.6 \\
\hline 6 & $21 / 07 / 1986$ & Chalfant Valley & Benton & 5.77 & 24.25 & 0.32 & 2.9 \\
\hline 7 & $21 / 07 / 1986$ & Chalfant Valley & Bishop_Paradise Lodge & 5.77 & 14.99 & 0.34 & 2.2 \\
\hline 8 & $21 / 07 / 1986$ & Chalfant Valley & Lake Crowley_Shehorn & 5.77 & 24.37 & 0.31 & 2.1 \\
\hline 9 & 01/10/1987 & $\begin{array}{l}\text { Whittier Nar- } \\
\text { rows }\end{array}$ & Pomona - 4th and Locust & 5.99 & 25.11 & 0.37 & 2.5 \\
\hline 10 & 17/08/1999 & Duzce & Lamont 1061 & 7.14 & 11.46 & 0.28 & 2.7 \\
\hline 11 & 17/01/1994 & Northridge & $\begin{array}{l}\text { Castaic_-Old Ridge } \\
\text { Route }\end{array}$ & 6.05 & 29.29 & 0.19 & 2.8 \\
\hline 12 & 21/09/1999 & Chi-Chi & TCU073 & 6.2 & 19.06 & 0.20 & 3 \\
\hline
\end{tabular}

\subsubsection{Collapse limit state criterion}

The interstorey drift ratio of $4 \%$ is determined as the collapse limit state criterion in this study, as presented by Kappos et al. (2006). For each ground motion, the collapse intensity is determined as the intensity, for which the maximum interstorey drift exceeds the predetermined interstorey drift.

ratio of $4 \%$. The IDA curves corresponding to the 12 ground motions used in this study and a vertical line denoting the selected drift-based collapse criterion are shown in the following Fig. 8.

\subsubsection{Fragility curve}

The collapse fragility curve of the RC building for each value of the selected intensity measure (PGA) is derived by the probability of exceedance of the drift-based collapse criterion for this intensity, based on the results of the IDA curves (Fig. 8).

Assuming a lognormal distribution, the corresponding parameters can be estimated from the obtained collapse intensities (Baker 2015). The cumulative distribution function and the corresponding parameters $(\theta, \beta)$ are determined using Eqs. 3, 4 and 5:

$$
\begin{gathered}
P(C \mid I M=x)=\Phi\left(\frac{\ln (x / \theta)}{\beta}\right) \\
\ln (\theta)=\frac{1}{n} \sum \ln \left(I M_{i}\right)
\end{gathered}
$$




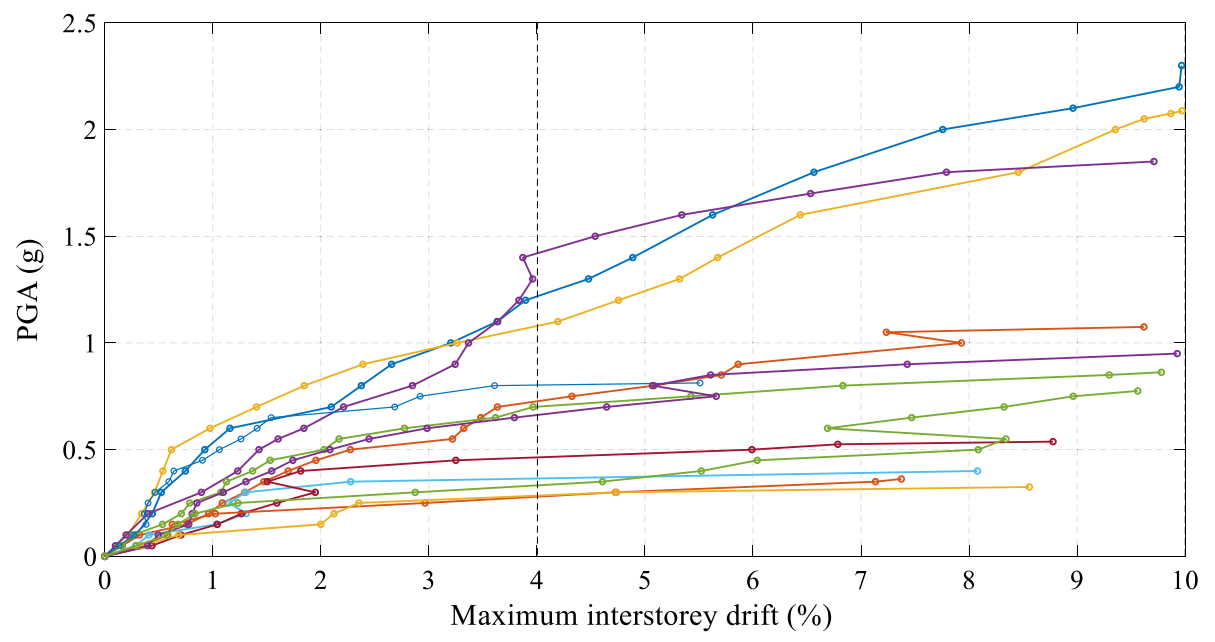

Fig. 8 IDA curves of the RC frame building

$$
\beta=\sqrt{\frac{1}{n-1} \sum\left(\ln \left(I M_{i} / \theta\right)^{2}\right.}
$$

The fragility curve of the building presented in Fig. 5, derived through the aforementioned procedure (Amrein 2020), is shown in Fig. 9.

\subsubsection{Probability of collapse}

The mean annual rate of collapse can be calculated through the integration of the fragility curve of the building (Fig. 9) over the seismic hazard curve (Fig. 1) using Eq. (6) (Eads et al. 2013):

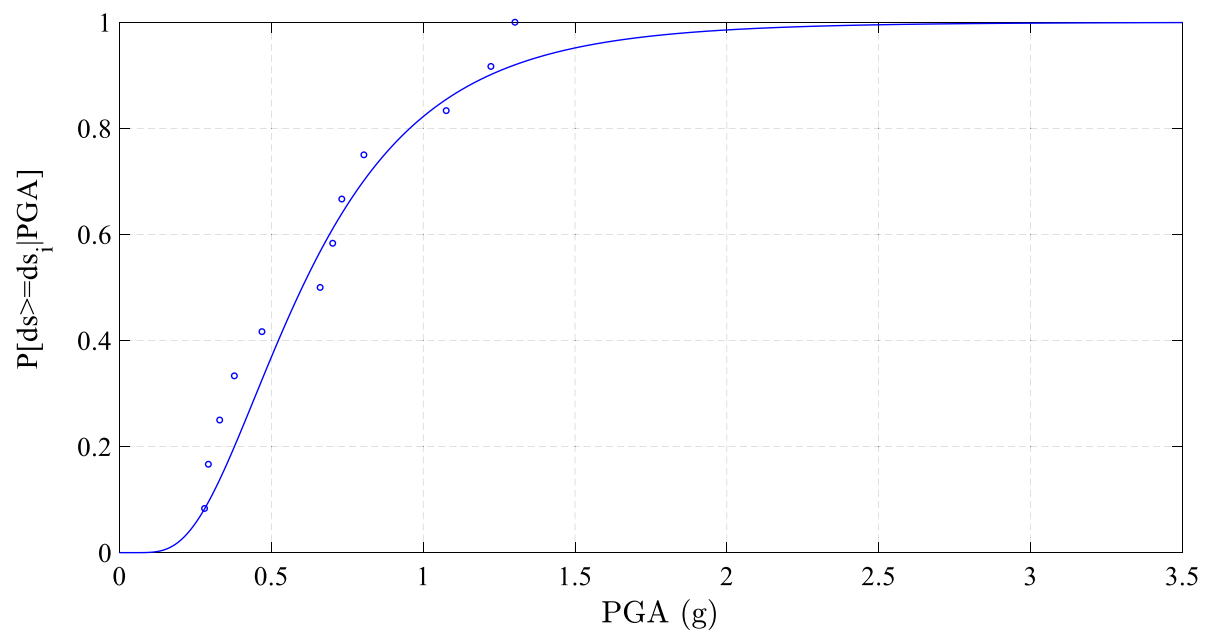

Fig. 9 Fragility curve of the RC frame building 


$$
\lambda_{c}=\sum_{1}^{\infty} P\left(C \mid i m_{i}\right) \cdot\left|\frac{d \lambda_{I M}\left(i m_{i}\right)}{d(i m)}\right| \cdot \Delta i m
$$

The probability of collapse during the service life of the building $T_{L}$ can be then calculated using Eq. (7), assuming that the occurrence of earthquakes in time follows a Poisson distribution (Eads et al. 2013):

$$
P_{c}\left(\text { in } T_{L} \text { years }\right)=1-e^{-\lambda_{c} \cdot T_{L}}
$$

The derived probability of collapse of the building (Model A) for varying values of its service life and two different locations (Sion and Athens) is shown in Fig. 10. As shown in the Figure, the compliance factor of the building located in Sion $\alpha_{s}=1.40$ leads to a probability of collapse of $1 \%$ in 50 years. However, the location of the same building in a region of higher seismic hazard, such as Athens, with a compliance $\alpha_{s}=0.83$ corresponds to a five times higher probability of collapse: $5 \%$ in 50 years. This result is in accordance with the investigation of Kappos et al. (2007), who determined the economic losses attributed to RC frame structures of low code-compliance subjected to the 1999 Athens earthquake.

\section{Parametric investigation}

A parametric investigation was performed in this study following the proposed methodology to extend the results obtained for one building to four RC frame buildings of varying compliance.

Thus, the longitudinal reinforcement of the RC frame building shown in Fig. 5 (Model A) was reduced to represent three additional RC frame building classes of lower seismic code compliance, denoted as Model B, Model C and Model D. The longitudinal reinforcement diameters and the strength-based compliance factors $\alpha_{\mathrm{s}}$ of the four models according to the Swiss and the Greek seismic code provisions are shown in Table 3.

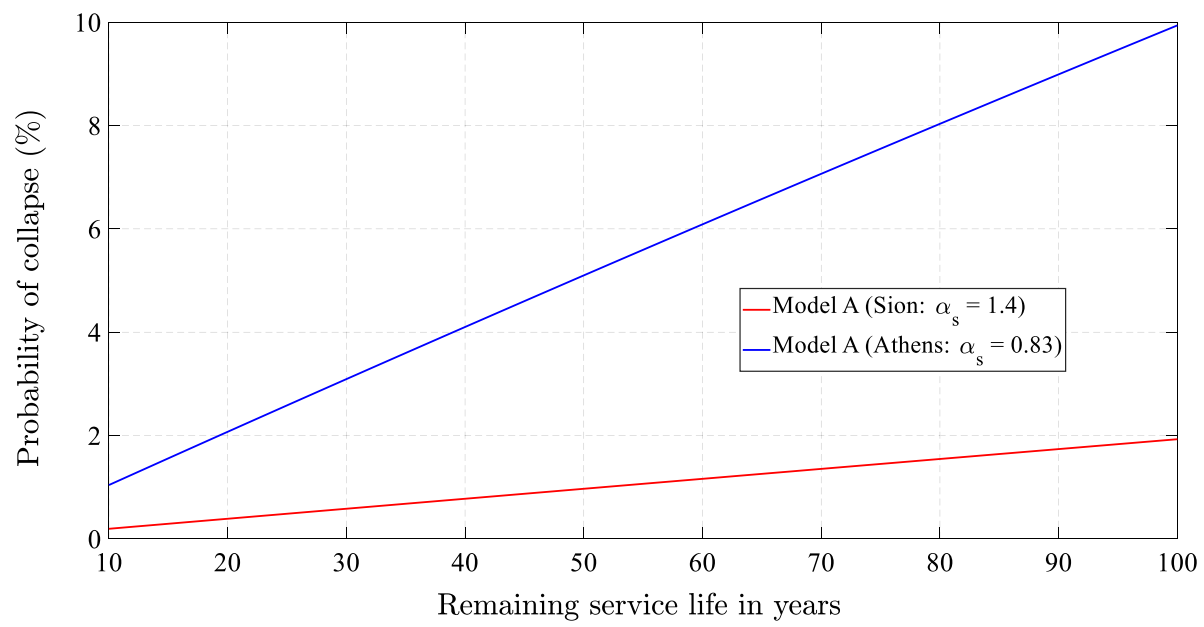

Fig. 10 Probability of collapse of the RC frame building for varying values of the service life $T_{L}$ and two different locations: Sion (Switzerland) and Athens (Greece) 
Table 3 Longitudinal reinforcement diameters and compliance factor values for the four building models

$\begin{array}{llll}\text { Column } & \text { Beam } & \begin{array}{l}\text { Compliance factor } \alpha_{s} \text { (Swiss } \\ \text { Code Provisions) }\end{array} & \begin{array}{l}\text { Compliance factor } \alpha_{s} \\ \text { (Greek Code Provi- } \\ \text { sions) }\end{array} \\ \varnothing 25 / \varnothing 20 & \emptyset 14 / \varnothing 12 & 1.40 & 0.83 \\ \varnothing 22 / \varnothing 18 & \varnothing 12 / \varnothing 10 & 1.18 & 0.67 \\ \varnothing 20 / \varnothing 16 & \emptyset 10 / \varnothing 18 & 0.92 & 0.49 \\ \varnothing 18 / \varnothing 14 & \varnothing 8 / \varnothing 8 & 0.62 & 0.34\end{array}$

The pushover curves of the buildings for varying vaues of their compliance, defined according to Greek seismic code provisions, are presented in Fig. 11.

\subsection{IDA curves of the four building models of varying compliance}

The IDA curves for the four buildings types of varying seismic code compliance, defined according to the Greek seismic code provisions, are shown in Fig. 12. As presented in the figure, the dynamic instabilities manifested by increased values of drift for small intensity increments are observed for more ground motions when the seismic code compliance decreases, as observed by Tsiavos et al. $(2017,2020)$. These instabilities indicate more extensive structural collapse (Vamvatsikos and Cornell 2002; D'Ayala et al. 2015) for decreased seismic code compliance and can be more clearly illustrated in the fragility curves shown in Fig. 13 for the four selected building models of varying code compliance.

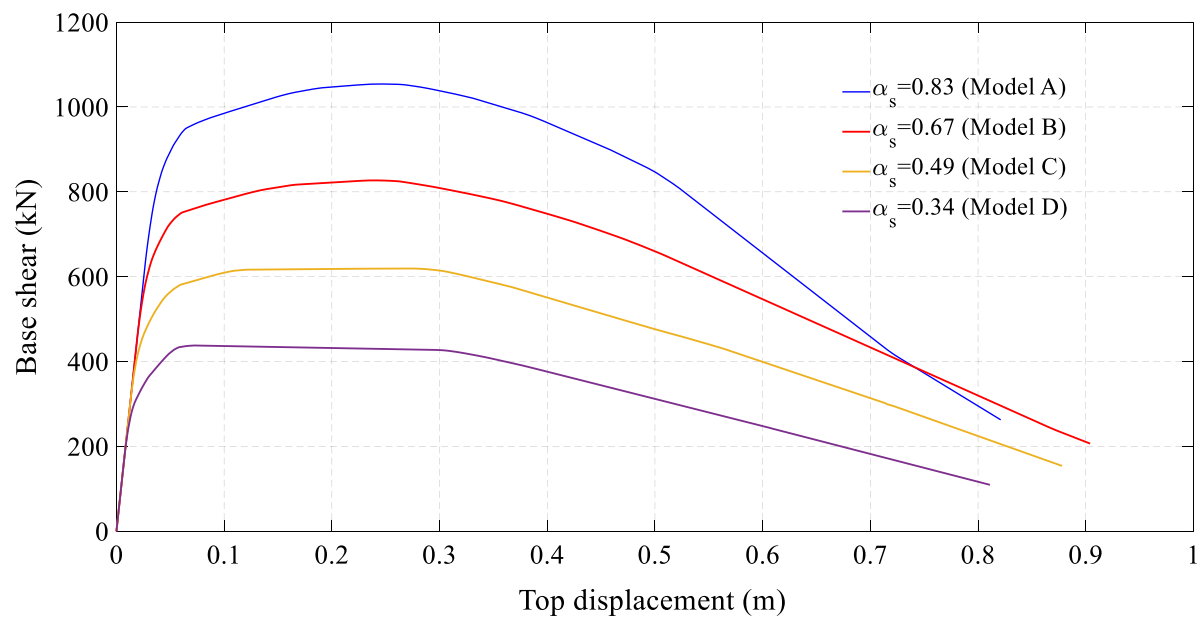

Fig. 11 Pushover curves for building models A, B, C and D (compliance factors per Greek seismic code provisions) 


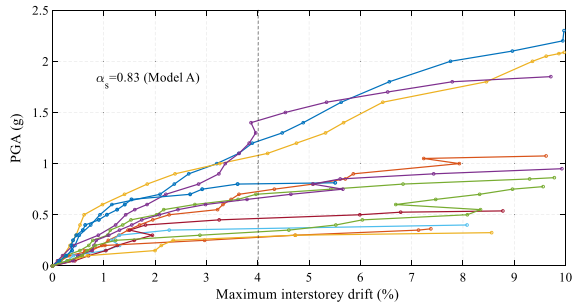

(a)

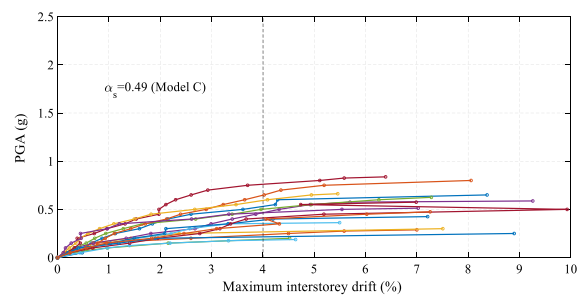

(c)

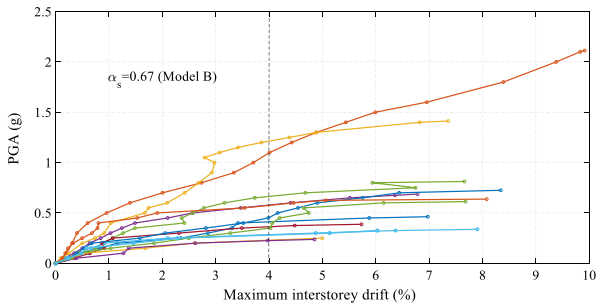

(b)

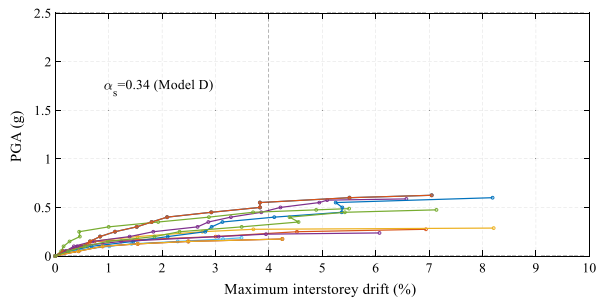

(d)

Fig. 12 IDA curves for a Model A, b Model B, c Model C and d Model D

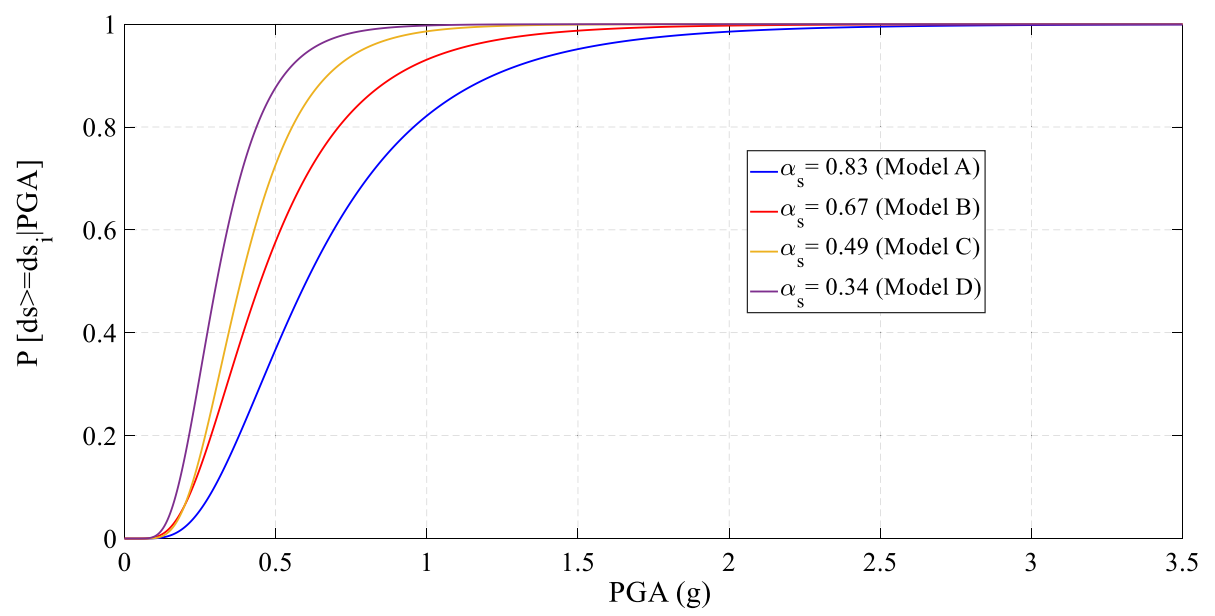

Fig. 13 Fragility curves for building models A, B C and D (compliance factors per Greek seismic code provisions)

\subsection{Fragility curves of the four building models of varying compliance}

As shown in Fig. 13, the fragility curves become steeper due to a decrease of the code compliance from 0.83 to 0.67 (Model A to Model B) indicating higher probability of exceedance of the collapse limit state for these buildings at all intensity levels. This increase of the probability of exceedance manifests itself only for intensities (PGA) exceeding $0.25 \mathrm{~g}$ when the code compliance is further reduced from 0.67 to 0.49 (Model B to Model C). However, this collapse probability increase due to a reduction 
of the compliance factor from 0.49 to 0.34 (Model C to Model D) is more uniform and intensity-independent.

\subsection{Probability of collapse of the four building models of varying compliance}

The mean annual rate of collapse of each of the four buildings $\lambda_{c}$ is calculated through the integration of the fragility curve of the building (Fig. 13) over the seismic hazard curve using Eq. (6) (Eads et al. 2013). The emerging deaggregation of the collapse rate $\lambda_{c}$ is shown in Fig. 14 for Sion, Switzerland and in Fig. 15 for Athens, Greece. These graphs indicate the contributions of different levels of ground motion intensity to the total collapse risk (Eads et al. 2013).

As presented in both Figures, the ground motion intensity, at which the maximum annual rate of collapse occurs, shifts from the initial value of PGA $=0.35 \mathrm{~g}$ to smaller intensities when the code compliance of the building decreases, leading to a PGA $=0.25 \mathrm{~g}$ for Model D ( $\alpha_{s}=0.41$, according to the Greek seismic code provisions).

Along these lines, the low seismic code compliance of RC buildings increases the spectrum of ground motions that can can lead to collapse of these buildings, thus increasing their seismic vulnerability and seismic risk, as shown by Iervolino et al. (2007). This increase of seismic risk for lower values of compliance is expressed through the estimation of the corresponding probabilities of collapse during the service life for Sion and Athens locations shown in Fig. 16 and Fig. 17, respectively. The decrease of the compliance factor from $\alpha_{s}=1.40$ to $\alpha_{s}=0.62$ leads to an increase of the collapse probability for a 50 year service life from 1 to $3 \%$ for Sion. This increase of collapse probability for a decrease of the corresponding compliance factor from $\alpha_{s}=0.83$ to $\alpha_{s}=0.34$ is much more pronounced for regions of high seismic hazard, such as Athens, where the collapse probability increases from 5 to $15 \%$ for a 50 year service life.

The American Seismic Code Provisions (ASCE 7 2016; ASCE 41 2017; Luco et al. 2007) prescribe a risk-based ground motion selection procedure for the design of new structures that corresponds to an accepted level of seismic risk, expressed by a probability
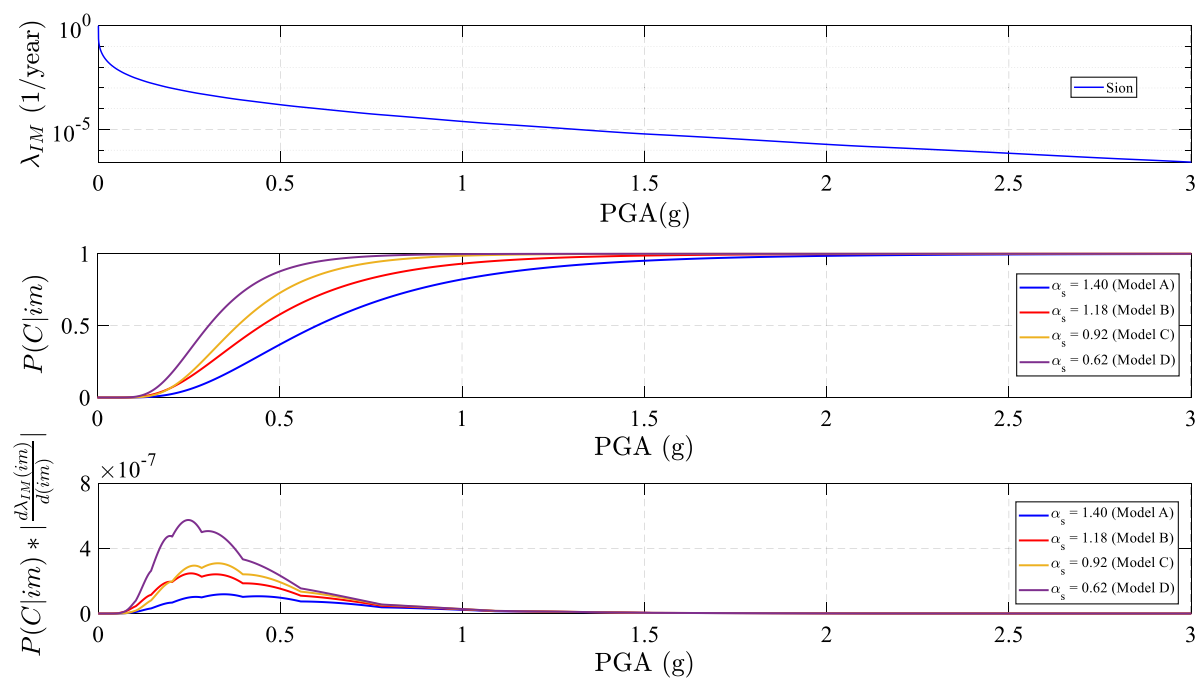

Fig. 14 Deaggregation of mean annual collapse rate $\lambda_{c}$ for Sion, Switzerland 

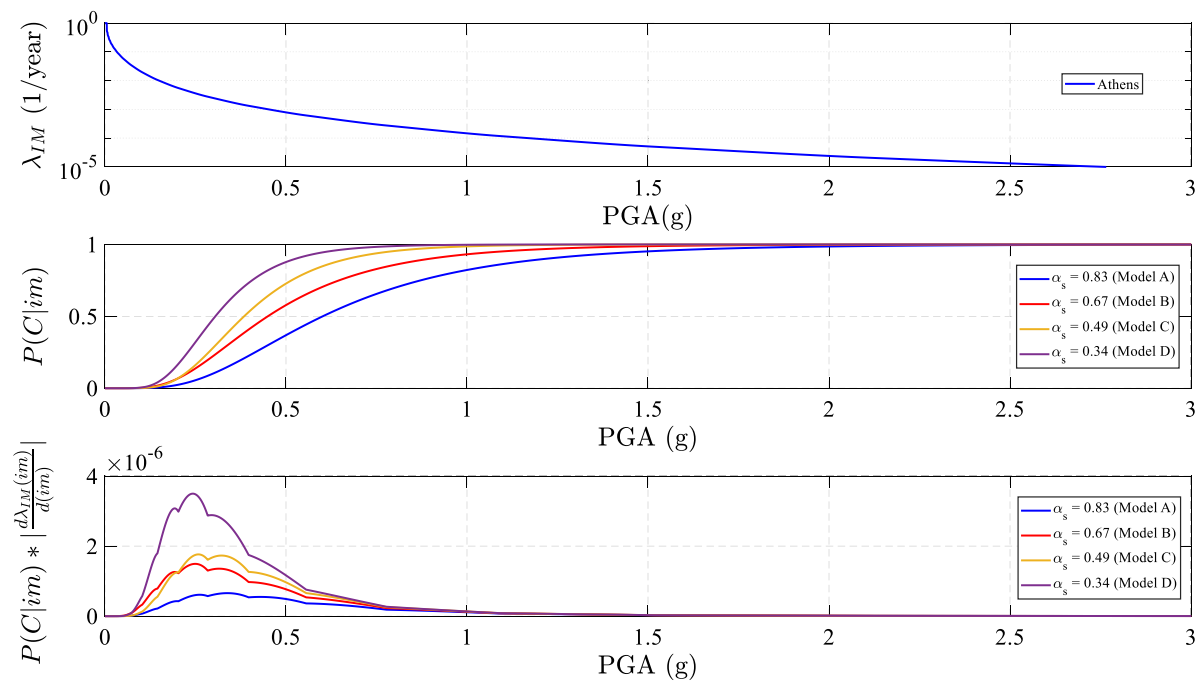

Fig. 15 Deaggregation of mean annual collapse rate $\lambda_{c}$ for Athens, Greece

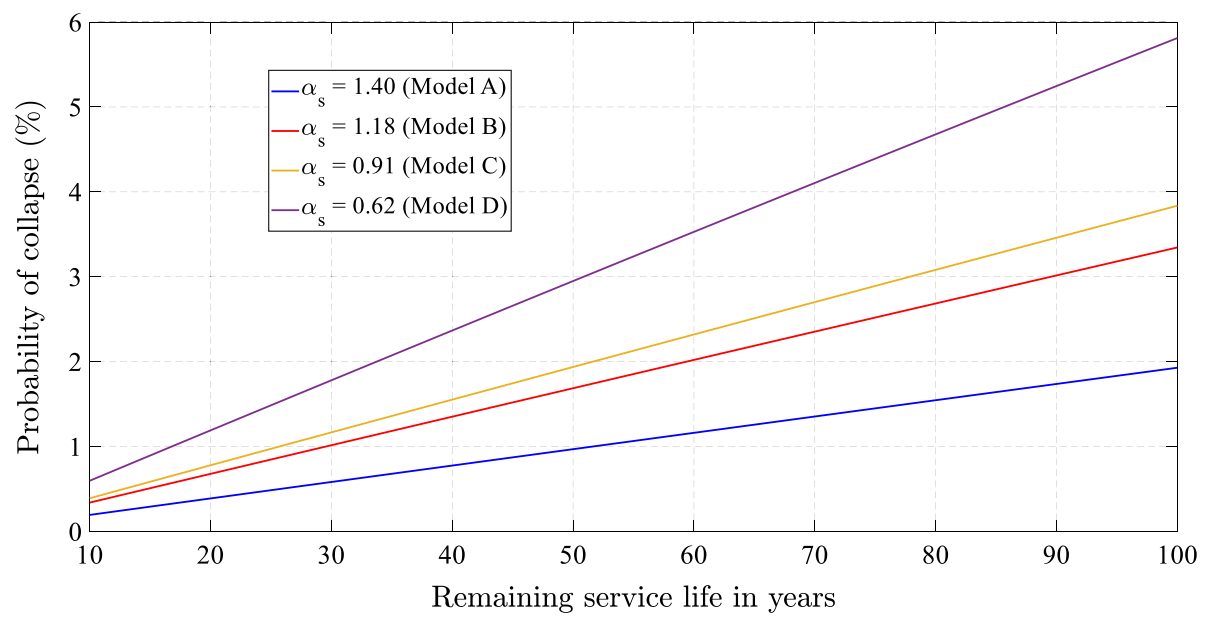

Fig. 16 Probability of collapse of RC frame buildings of varying compliance located in Sion

of collapse of $1 \%$ in 50 years. Interestingly, the investigated RC frame building with compliance $\alpha_{s}=1.40$ located in Sion corresponds roughly to this allowable seismic risk level with a probability of collapse of $0.97 \%$ in 50 years (Fig. 16). However, locating the same $\mathrm{RC}$ frame building in Athens leads to reduced code compliance expressed by strengthbased compliance factor values below 1 , which are associated with probabilities of collapse that are significantly higher than the aforementioned value of $1 \%$ in 50 years (Fig. 17).

Within this frame, the presented compliance-based, seismic risk assessment of existing structures should not be building-specific, but also location-dependent: Different communities will be led to different seismic assessments and different optimal seismic retrofit 


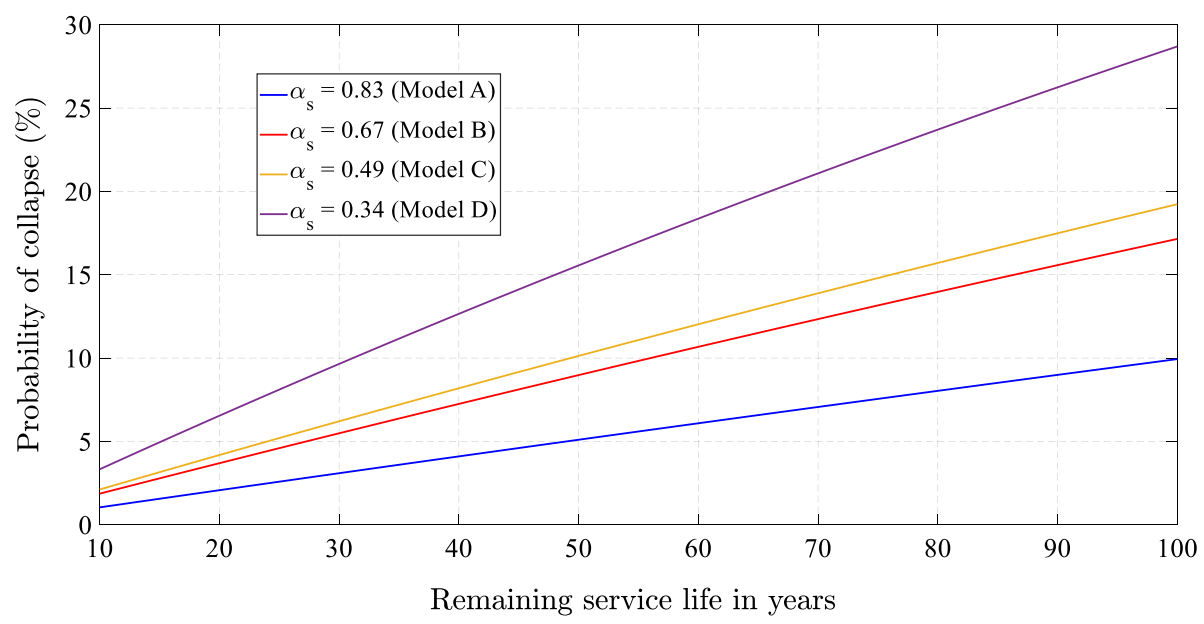

Fig. 17 Probability of collapse of RC frame buildings of varying compliance located in Athens

decisions about their existing non-compliant infrastructure, depending on their seismic hazard level and an accepted level of seismic risk. Determining the code compliance that corresponds to the accepted level of seismic risk is of paramount importance in this process: the additional risk posed by existing structures that do not satisfy the compliance associated with the accepted seismic risk level will have to be mitigated either by seismic retrofitting or demolishion and replacement, depending on their remaining service life and a holistic cost-benefit analysis.

\section{Conclusions}

This paper presents a methodology for the seismic evaluation of existing structures, based on their seismic code compliance. The normalized metric that is chosen to quantify the code compliance of existing structures is defined as the compliance factor of the structure. This dimensionless metric normalizes the seismic capacity of an existing structure with the seismic demand for a new structure designed at the same location for a predetermined hazard level.

The inelastic seismic behavior of RC frame buildings of varying compliance was analytically investigated in this study to illustrate the application of the proposed methodology for the seismic evaluation of existing structures using the PBEE toolbox (Dolšek 2010). Four RC frame buildings of varying strength were modelled to represent typical examples of RC frame buildings, designed and constructred before the introduction of the modern seismic code provisions. The strength and displacement capacity of these buildings was derived based on static pushover analysis. The strength-based compliance factors of the four buildings were calculated based on bilinear idealizations of the obtained pushover curves and elastic seismic design spectra.

The four RC buildings of varying compliance were subjected to a ground motion excitation ensemble using Incremental Dynamic Analysis (IDA), implemented through the PBEE toolbox. The comparison of the obtained IDA curves with a collapse criterion established for RC frame buildings led to the development of compliance-based fragility curves 
for the four buildings. The probability of collapse of the four buildings was derived through the integration of the fragility curves over the seismic hazard curves for two locations representing regions of moderate and high seismic hazard: Sion (Switzerland) and Athens (Greece).

The proposed methodology is easy to use and comprises three steps: The estimation of seismic hazard in the location of the structure, the determination of the compliance of the structure to the existing seismic code provisions and the quantification of the seismic risk of the structure, expressed by its probability of collapse.

This study focused on the application of this methodology to an RC frame building of a predetermined geometry and strength for two seismic hazard levels. However, the presented methodology can be applied for the determination of the relation between the code compliance and the seismic risk of a wide range of existing RC, masonry, steel or timber structures of varying geometries and can be performed for more regions, representing different seismic hazard levels. This determination can provide a location-dependent benchmark database that leads to a direct, compliance-based estimation of the seismic risk of existing structures of a known geometry and building typology. The determination of seismic risk targeted-compliance values in this database could provide a valuable tool to local authorities towards a fast, compliance-based seismic assessment of the existing building inventories at a community level.

Along these lines, this methodology can lay the basis for the efficient determination of the seismic risk of existing structures of varying code compliance, expressed by their compliance factors. This seismic risk assessment can yield valuable insight into the decisionmaking process for the prioritization of the seismic retrofitting of existing structures: The optimal seismic retrofitting strategy for the seismic upgrade of our existing infrastructure can be chosen as the one leading to a seismic risk level accepted by our communities. Within this frame, this seismic risk-based assessment and decision-making process can lead to the development of resilient communities.

Funding Open Access funding provided by ETH Zurich. The research presented in this study was funded by ETH Zurich.

\section{Declarations}

Conflict of interest The authors of this paper certify that they have no affiliations with or involvement in any organization or entity with any financial interest (such as honoraria; educational grants; participation in speakers' bureaus; membership, employment, consultancies, stock ownership, or other equity interest; and expert testimony or patent-licensing arrangements), or non-financial interest (such as personal or professional relationships, affiliations, knowledge or beliefs) in the subject matter or materials discussed in this manuscript.

Open Access This article is licensed under a Creative Commons Attribution 4.0 International License, which permits use, sharing, adaptation, distribution and reproduction in any medium or format, as long as you give appropriate credit to the original author(s) and the source, provide a link to the Creative Commons licence, and indicate if changes were made. The images or other third party material in this article are included in the article's Creative Commons licence, unless indicated otherwise in a credit line to the material. If material is not included in the article's Creative Commons licence and your intended use is not permitted by statutory regulation or exceeds the permitted use, you will need to obtain permission directly from the copyright holder. To view a copy of this licence, visit http://creativecommons.org/licenses/by/4.0/. 


\section{References}

Amrein P (2020) Influence of strength compliance on the probability of collapse of an existing RC frame building, Master Thesis at ETH Zurich supervised by Dr. Anastasios Tsiavos and Prof. Bozidar Stojadinovic, Autumn

Anagnos T, Rojahn C, Kiremidjian AS (1995) NCEER-ATC joint study on fragility of buildings. Techn. Rep. NCEER 95-0003, State Univ. of NY at Buffalo

Applied Technology Council (1996) Seismic evaluation and retrofit of concrete buildings, Report ATC-40. Redwood City (CA)

ASCE 41-17, Seismic evaluation and retrofit of existing buildings, American Society of Civil Engineers

ASCE 7-16, Minimum Design Loads for Buildings and Other Structures, American Society of Civil Engineers

Baker JW (2015) Efficient analytical fragility function fitting using dynamic structural analysis. Earthq Spectra 31(1):579-599

Belejo A, Barbosa AR, Bento R (2017) Influence of ground motion duration on damage index-based fragility assessment of a plan-asymmetric non-ductile reinforced concrete building. Eng Struct 15:1682-1703

Bender N, Tsiavos A, Pilotto M, Stojadinovic B (2019) Engineering collapse-probability-based seismic retrofit design for existing bridges, In: 11th National Conference on Earthquake Engineering (11NCEE), Los Angeles, CA, USA

Bender N (2017) Compliance factors for existing structures: calibration and evaluation, Master Thesis at ETH Zurich supervised by Dr. Anastasios Tsiavos and Prof. Bozidar Stojadinovic

Bento R, Bhatt C, Pinho R (2010) Using nonlinear static procedures for seismic assessment of the 3D irregular SPEAR building. Earthq Struct 1(2):177-195

Beyer K, Tondelli M, Petry S, Peloso S (2015) Dynamic testing of a four-storey building with reinforced concrete and unreinforced masonry walls: prediction, test results and data set. Bull Earthq Eng 13(10):3015-3064

Borzi B, Pinho R, Crowley H (2008) Simplified pushover-based vulnerability analysis for large-scale assessment of RC buildings. Eng Struct 30(3):804-820

Cantagallo C, Camata G, Spacone E, Corotis R (2012) The variability of deformation demand with ground motion intensity. Probab Eng Mech 28:59-65

Carvalho G, Bento R, Bhatt C (2013) Nonlinear static and dynamic analyses of reinforced concrete buildings-comparison of different modelling approaches. Earthq Struct 4(5):451-470

Chaulagain H, Rodrigues H, Silva V, Spacone E, Varum H (2016) Earthquake loss estimation for the Kathmandu valley. Bull Earthq Eng 14:59-88

Cornell CA, Jalayer F, Hamburger RO, Foutch DA (2002) Probabilistic basis for 2000 SAC Federal Emergency Management Agency steel moment frame guidelines. J Struct Eng 128(4):526-533

Couto R, Requena-García-Cruz MV, Bento R (2020) Seismic capacity and vulnerability assessment considering ageing effects: case study—three local Portuguese RC buildings. Bull Earthq Eng. https://doi. org/10.1007/s10518-020-00955-4

Crowley H, Colombi M, Calvi GM, Pinho R, Meroni F, Cassera A (2008) Application of a prioritization scheme for seismic intervention in schools buildings in Italy. In: The 14th world conference on earthquake engineering, Beijing, China

D'Ayala D, Meslemn A, Vamvatsikos D, Porter K, Rossetto T, Silva V (2015) Guidelines for analytical vulnerability assessment of low/mid-rise buildings, gem vulnerability global component project. doi: https://doi.org/10.13117/GEM.VULN-MOD.TR2014.12

Dolšek M (2008) PBEE toolbox-examples of application, Version 1. University of Ljubljana. http://ice4r isk.slo-projekt.info/applications.html

Dolšek M (2010) Development of computing environment for the seismic performance assessment of reinforced concrete frames by using simplified nonlinear models. Bull Earthq Eng 8(6):1309-1329

Duvernay B, Kölz E, Jamali N, Michel C (2018) Is the residual risk related to the Swiss building code provisions acceptable? In: Proceedings, 16th European Conference on Earthquake Engineering (16ECEE), 18-21 June, 2018, Thessaloniki, Greece

Eads L, Miranda E, Krawinkler H, Lignos DG (2013) An efficient method for estimating the collapse risk of structures in seismic regions. Earthq Eng Struct Dyn 42(1):25-41

Elwood K, Holmes W, Comartin C, Heinz J, Rojahn C, Dragovic J, McCabe S, Mahoney M (2012) Collapse assessment and mitigation of nonductile concrete buildings: ATC-76-5/ATC-78/ATC-95, in 15th World Conference on Earthquake Engineering, Lisbon, Portugal 
EN 1998-1 (2004) (English): Eurocode 8: Design of structures for earthquake resistance - Part 1: General rules, seismic actions and rules for buildings [Authority: The European Union Per Regulation 305/2011, Directive 98/34/EC, Directive 2004/18/EC

EN 1992-1-1 (2004) (English): Eurocode 2: Design of concrete structures - Part 1-1: General rules and rules for buildings [Authority: The European Union Per Regulation 305/2011, Directive 98/34/EC, Directive 2004/18/EC]

European Facilities for Earthquake Hazard and Risk (2017) Seismic Hazard Platform, Accessed 15.10.2020: http://www.efehr.org/en/hazard-data-access/hazard-curves/.

Fajfar P (1999) Capacity spectrum method based on inelastic demand spectra. Earthq Eng Struct Dyn 28:979-993

Fardis MN, Papailia A, Tsionis G (2012) Seismic fragility of RC framed and wall-frame buildings designed to the EN-Eurocodes. Bull Earthq Eng 10:1767-1793

Fardis M, Negro P (2005) Seismic performance assessment and rehabilitation of existing buildings. In: Proceedings of the international work, SPEAR, Ispra, Italy

Fardis MN (1996) Experimental and numerical investigations on the seismic response of RC infilled frames and recommendations for code provisions. ECOEST/PREC 8, Rep. No. 6, LNEC, Lisbon

Federal Emergency Management Agency (2003) HAZUS-MH Technical Manual. Washington

Freeman SA, Nicoletti JP, Tyrell JV (1975) Evaluations of existing buildings for seismic risk- A case study of Puget Sound Naval Shipyard, Bremerton, Washington, In: Proceedings of the 1st National Conference of Earthquake Engineering, Berkeley, California

Freeman SA (1998) Development and use of capacity spectrum method, In: Proceedings of the 6th National Conference of Earthquake Engineering, Seattle, Oakland

Galanis P, Sycheva A, Mimra W, Stojadinovic B (2018) A framework to evaluate the benefit of seismic upgrading. Earthq Spectra 34:527-548

Grant DN, Bommer JJ, Pinho R, Calvi GM, Goretti A, Meroni F (2007) A prioritization scheme for seismic intervention in school buildings in Italy. Earthq Spectra 23(2):291-314

Iervolino I, Manfredi G, Polese M, Verderame GM, Fabbrocino G (2007) Seismic risk of R.C. building classes. Eng Struct 29(5):813-820

Iervolino I, Spillatura A, Bazzurro P (2018) Seismic Reliability of Code-Conforming Italian Buildings. J Earthq Eng 22(2):5-27

Jalayer F, Franchin P, Pinto PE (2007) A scalar damage measure for seismic reliability analysis of RC frames. Earthquake Eng Struct Dynam 36(13):2059-2079

Jalayer F, Cornell A (2002) A technical framework for probability-based demand and capacity factor (DCFD) seismic formats. RMS Technical Rep. No. 43 to the PEER Center, Dept. of Civil and Environmental Engineering, Stanford Univ., Stanford, Calif. Kennedy, R. P., and Short, S. A

Kappos A, Panagopoulos G (2010) Fragility curves for reinforced concrete buildings in Greece. Struct Infrastruct Eng 6(1-2):39-53. https://doi.org/10.1080/15732470802663771

Kappos A, Panagopoulos G, Panagiotopoulos C, Penelis G (2006) A hybrid method for the vulnerability assessment of R/C and URM buildings. Bull Earthq Eng 4:391-413

Kappos AJ, Lekidis V, Panagopoulos G, Sous I, Theodulidis N, Karakostas Ch, Anastasiadis T, Salonikios T, Margaris B (2007) Analytical estimation of economic loss for buildings in the area struck by the 1999 Athens earthquake and comparison with statistical repair costs. Earthq Spectra 23(2):333-355

Kostinakis A, Athanatopoulou A, Morfidis K (2015) Correlation between ground motion intensity measures and seismic damage of 3D R/C buildings. Eng Struct 82:151-167

Liel A, Haselton C, Deierlein G, Baker J (2007) Assessing the seismic collapse risk of reinforced concrete frame structures, including the effects of modeling uncertainties. Special Workshop on Risk Acceptance and Risk Communication, Stanford University, pp 26-27

Luco N, Ellingwood BR, Hamburger RO, Hooper J D, Kimball JK, Kircher CA (2007) Risk-targeted versus current seismic design maps for the conterminous United States. SEAOC 2007 Convention Proceedings, Structural Engineers Association of California, Sacramento, California

Masi A (2003) Seismic Vulnerability Assessment of Gravity Load Designed R/C Frames. Bull Earthq Eng 1(3):371-395

MathWorks (2007) MATLAB the language of technical computing

Mazzoni S, McKenna F, Scott MH, Fenves GL (2006) Open system for earthquake engineering simulation. University of California, Berkeley

McKenna F, Fenves GL, Scott MH (2000) Open system for earthquake engineering simulation. University of California, Berkeley

Milosevic J, Cattari S, Bento R (2020) Definition of fragility curves through nonlinear static analyses: procedure and application to a mixed masonry-RC building stock. Bull Earthq Eng 18:513-545. https://doi.org/10.1007/s10518-019-00694-1 
Negro P, Verzeletti G, Magonette GE, Pinto AV (1994) Tests on a fourstorey full-scale R/C frame designed according to Eurocodes 8 and 2: Preliminary Report, European Commission, Report EUR 15879

Park Y-J, Ang A-H-S (1985) Seismic damage analysis of reinforced concrete buildings. J Struct Eng ASCE 111(4):740-757

PEER NGA Strong Motion Database (2018) Pacific Earthquake Engineering Research Center, University of California, Berkeley, available at. https://ngawest2.berkeley.edu/

Pinho R, Marques M, Monteiro R, Casarotti C (2013) Delgado R (2013) Evaluation of nonlinear static procedures in the assessment of building frames. Earthq Spectra 29(4):1459-1476

Pinho R, Antoniou S, Pietra D (2006) A displacement-based adaptive pushover for seismic assessment of steel and reinforced concrete buildings. In: Proceedings of the Eighth US national conference on earthquake engineering, San Francisco, U.S.A.; Paper No. 1701

Shahnazaryan D, O'Reilly GJ (2021) Integrating expected loss and collapse risk in performance-based seismic design of structures. Bull Earthq Eng. https://doi.org/10.1007/s10518-020-01003-X

SIA 269/8 (2017) Maintenance of structures-Earthquake (Erhaltung von Tragwerken-Erdbeben)

Silva V, Akkar S, Baker J, Bazzurro P, Castro JM, Crowley H, Dolšek M, Galasso C, Lagomarsino S, Monteiro R, Perrone D, Pitilakis K, Vamvatsikos D (2019) Current challenges and future trends in analytical fragility and vulnerability modeling. Earthq Spectra 35(4):1927-1952

Singhal A, Kiremidjian AS (1996) A method for probabilistic evaluation of seismic structural damage. J Struct Eng ASCE 122(12):1459-1467

Tsiavos A, Stojadinovic B (2016) A probabilistic approach towards and evaluation of existing code provisions for seismically isolated structures, In: European Congress on computational methods in applied sciences and engineering (ECCOMAS), Crete Island, Greece

Tsiavos A, Stojadinovic B (2019) Constant yield displacement procedure for seismic evaluation of existing structures. Bull Earthq Eng 17:2137-2164. https://doi.org/10.1007/s10518-018-00532-w

Tsiavos A, Schlatter D, Markic T, Stojadinovic B (2017) Experimental and analytical investigation of the inelastic behavior of structures isolated using friction pendulum bearings. Procedia Eng 199:465-470

Tsiavos A, Bender N, Stojadinovic B (2018) Collapse-probability-based compliance factors for seismic evaluation of existing structures. In: Proceedings of the 16th European conference on earthquake engineering, 10405, Thessaloniki, Greece

Tsiavos A, Haladij P, Sextos A, Alexander NA (2020) Analytical investigation of the effect of a deformable sliding layer on the dynamic response of seismically isolated structures. Structures 27:2426-2436

Vamvatsikos D, Cornell CA (2002) Incremental dynamic analysis. Earthq Eng Struct Dyn 31(3):491-514

Vamvatsikos D, Cornell CA (2004) Applied incremental dynamic analysis. Earthq Spectra 20(2):523-553

Vamvatsikos D, Cornell CA (2006) Direct estimation of the seismic demand and capacity of oscillators with multilinear static pushovers through Incremental dynamic analysis. Earthq Eng Struct Dyn 35(9):1097-1117

Yakut Y, Y1lmaz H (2008) Correlation of deformation demands with ground motion intensity. J Struct Eng 134(12):1818-1828

Zeris C, Vintzileou E, Repapis C (2002) Structural Overstrength Evaluation of Existing Buildings. In: Proceedings of the 12th European conference on earthquake engineering, London, U.K, CD-ROM, Paper 115, Elsevier Science, Amsterdam

Zeris C, Giannitsas P, Alexandropoulos K, Vamvatsikos D (2006) Inelastic modeling sensitivity of the predicted seismic performance of an existing RC Building, Paper No: 980, In: Proceedings of the thirteenth european conference on earthquake engineering, Geneva

Zeris C, Repapis C (2018) Comparison of the seismic performance of existing RC buildings designed to different codes. Earthq Struct 14:505-523. https://doi.org/10.12989/eas.2018.14.6.505

Žižmond J, Dolšek M (2019) Formulation of risk-targeted seismic action for the force-based seismic design of structures. Earthq Eng Struct Dyn 48(12):1406-1428

Publisher's Note Springer Nature remains neutral with regard to jurisdictional claims in published maps and institutional affiliations. 